FACTA UNIVERSITATIS

Series: Physical Education and Sport, Vol. 18, No 1, 2020, pp. 219 - 228

https://doi.org/10.22190/FUPES190410019S

Research article

\title{
THE EFFECTS OF REGULAR CLASSES AND CLASSES WITH ADDITIONAL EXERCISES ON STUDENTS' MOTOR ABILITIES
}

\author{
UDC 796.01.012
}

\author{
Slađana Stanković1 ${ }^{1}$ Aleksandra Aleksić Veljković ${ }^{2}$ \\ $\check{Z ̌ i v o r a d ~ M a r k o v i c ́}^{1}$, Katarina Herodek ${ }^{2}$ \\ ${ }^{1}$ Faculty of Pedagogy, University of Kragujevac, Jagodina, Serbia \\ ${ }^{2}$ Faculty of Sport and Physical Education, University of Niš, Niš, Serbia
}

\begin{abstract}
The aim of the research was to examine and compare the effects of physical education (PE) classes with additional swimming training in relation to the regular teaching of PE on the motor abilities of students of a younger school age. A sample of 100 respondents was divided into two sub-samples in relation to the number of weekly exercises: a sub-sample of 50 students (control group-CG) with regular PE and a subsample of 50 students (experimental group-EG) who, besides their regular classes, had two additional weekly exercises in the form of swimming training. The training program of swimming courses was conducted for three months in the first semester of the 2015/2016 school year. Five standardized Eurofit battery tests were used to evaluate their motor abilities. The obtained results indicate that two additional weekly exercises in the form of swimming training caused statistically significant differences between the EG and the CG in long distance jogging, sit-ups for $30 \mathrm{~s}$ and a $20 \mathrm{~m}$ run test with a progressive increase in speed. The results suggest that swimming in addition to the already known impact on physiological characteristics positively influences the transformation of motor abilities in students of a younger school age.
\end{abstract}

Key words: Physical Education, Swimming, Motor Skills, Students of a Younger School Age

Received April 10, 2019/ Accepted April 12, 2020

Corresponding author: Aleksandra Aleksić Veljković

Faculty of Sport and Physical Education, University of Niš, Čarnojevića 10a, 18000 Niš, Serbia

Phone: + 38118 510900•E-mail: axy.gym@gmail.com

(C) 2020 by University of Niš, Serbia | Creative Commons License: CC BY-NC-ND 


\section{INTRODUCTION}

According to the experts, the way of teaching which today dominates in most elementary schools has numerous disadvantages. Teaching is subjected to criticism because it is thought to offer students superficial and useless knowledge that turns a student into a "wiseacre encyclopaedist" with a bunch of facts that often cannot be used in new and different situations and practical activities (Healey, 2005; Onurkan Aliusta \& Özer, 2017). On the other hand, the increasingly frequent use of educational technology inventions seriously jeopardizes the physical activity of students, who spend more time sitting on school benches (acquiring information from the overwhelming curriculum envisaged by the program), or in front of their computers and televisions (Swamidass \& Vulasa, 2009; Kloos et al., 2019).

It is important to note that human movement is not only closely related to physical, but also to the mental, social and psychological development. The future of our society depends on the physical potentials, mental abilities, emotional stability and social adaptation of children who are now growing and whose future we are concerned about. The conditions in which children grow and develop are not always stimulating. Urbanization, the modern way of life, mechanization, the burden of children with intellectual activities, the overall relationship of the social environment and its influence on children and their activities in it no longer act as stimuli, they do not encourage them to move. As a result, the goal of teaching physical education (PE) is to meet the needs of students for movement, contribute to the increase of their adaptive and creative abilities in contemporary living and working conditions, develop a health culture necessary for the preservation of health and the creation of a lasting habit of incorporating physical exercise into everyday life (Sawyer, 2004; Davies et al., 2013).

In spite of clearly defined goals, emphasis is still placed on the acquisition of knowledge in practice, and the physical engagement of students is ignored. Most authors (Radovanović et al., 2009; Kalaja, Jaakkola, Liukkonen, \& Watt, 2010; Tošić, 2011; Pešić et al., 2016) present the opinion that students need to provide physical engagement and movement in water at the earliest age. Swimming training can begin very early because swimming is the most appropriate content of PE in all ages. The fact is that the acquisition of swimming skills at the present time is limited by material-technical conditions and low efficiency of the process of initial swimming lessons (Farrell, 2007; Macejková, Masaryková, \& Labudová, 2008; Barbosa, Marinho, Costa, \& Silva, 2011).

Swimming training among children of a young school age is carried out mainly on the basis of methodological principles of training in swimming clubs. In the course of working with children of a younger school age, in addition to training a child to manage only in water, the deformities (most often of the spinal column) are prevented through training, which usually occurs with the child starting school. Due to poor musculature, physical inactivity, long sitting, children often experience deformities of the spinal column, which, apart from the aesthetic appearance, may adversely affect the functional abilities of certain organs, especially the locomotor apparatus. However, in the water, when the body is in a horizontal position, without load on the spine, movements are carried out without great effort, burdening the muscularity of the body evenly and effectively, and especially the muscles of the back, chest and shoulder belt. This work positively influences the strength of the entire musculature, which leads to corrections of 
the incorrect position of the body. Swimming allows the increased functioning of all systems in the body, primarily of the heart and respiratory system (Sutarto, Wahab, \& Zin, 2010). In addition, frequent changes in the outside temperature and water temperature activate the thermoregulatory protection mechanism of the body, and as a result, the body's resistance to various diseases increases. Staying in water contributes to the maintenance of body hygiene, improves the function of the skin, and at the same time increases its protective role.

The aim of the research was to examine and compare the effects of PE classes with additional swimming training in relation to the regular PE classes on the motor abilities of students of a younger school age.

\section{METHODS}

The research has a longitudinal experimental character (a pedagogical experiment with parallel groups of students of a younger school age), realized for the duration of one semester, in which the teaching of PE was organized in 30 school lessons. With the written consent of the schools and the parents, assessment of motor skills was carried out during regular PE classes. Estimates were made by professors of PE with previous research experience, so that the initial and final tests were performed by the same persons. For initial and final assessment, five variables of the Eurofit battery (Tsigilis, Douda, \& Tokmakidis, 2002; Gulías-González, Sánchez-López, Olivas-Bravo, Solera-Martínez, \& MartínezVizcaíno, 2014) were applied. It took three hours and the dynamics was as follows: during the first hour, the level of flexibility - the sit and reach test (EFPS in $\mathrm{cm}$ ) and the explosive power of leg muscles - a long-range jump (EFSD in $\mathrm{cm}$ ) were evaluated. During the second hour the repetitive strength of the abdominal muscles and the hip joint i.e., sit-ups for 30 $\mathrm{s}$ (EFLS in reps) and the isometric muscle force of the upper body and the bent arm hang i.e., strength and endurance (EFZG in s) were evaluated. Finally, during the third hour maximum aerobic endurance i.e., steady running at $20 \mathrm{~m}$ with progressive speed increase (EFIZ in s) was evaluated. The initial assessment established the level of motor skills, with the intention of raising it by means of the experimental program of swimming training, and evaluating it by the means of a final assessment at the end of the semester.

\section{Sample of participants}

The study was conducted on a sample of 100 participants aged $11 \pm 6$ years $($ Mean \pm SD), fourth grade elementary school children from the city of Niš.

The sample of participants was divided into two sub-samples. The CG ( $\mathrm{n}=50$, body height $152.09 \pm 5.68 \mathrm{~cm}$, body mass $44.37 \pm 8.18 \mathrm{~kg}$, Mean $\pm \mathrm{SD}$ ) consisted of participants who only attended regular PE classes. The EG of participants $(n=50$, body height $150.02 \pm 6.90 \mathrm{~cm}$, body mass $41.55 \pm 7.06 \mathrm{~kg}$, Mean \pm SD) had two additional weekly exercises in the form of swimming training (a total of 24 classes) in addition to their regular PE. All of the participants were healthy on the day of the initial and final assessment. 


\section{Description of the applied experimental program of swimming training}

The experimental program of training for non-swimmers was realized after obtaining consent from the school and parents, for a period of 12 weeks. The frequency of exercise was twice a week for 45 min., and the total number of hours was 24 . The experimental treatment was conducted with the fourth grade participants from the "Bubanjski heroji" elementary school in Niš, while the control treatment was realized with fourth grade participants from the "Stefan Nemanja" elementary school in Niš. At the end of the initial assessment, a 24-hour course started, during which the planned content was realized. The swimming training program was realized at the pools of the Sports Center "Čair" in Niš. The CG worked according to the standard plan of PE teaching (teaching content from the official PE program). The EG worked on the same program content with two additional exercises weekly in the form of swimming training. The swimming training program included: checking swimming knowledge, dryland workouts, breathing and looking under water exercises, getting used to being in water exercises, horizontal positioning and water skating exercises, water games, diving, jumping and learning basic swimming techniques. The elements that were used during the course of swimming training were selected in accordance with the relevant recommendations for training non-swimmers (Benjanuvatra, Edmunds, \& Blanksby, 2007; Girold, Maurin, Dugué, Chatard, \& Millet, 2007; Jorgić et al., 2010; Pyne \& Sharp, 2014; Stanković, Milanović, \& Marković, 2015). The goal of the swimming training program was to alleviate the fear of water, to get the participants to be alone in the water, for them to look under water, to keep lying on their back and stomach, to skate through the water, to dive, jump from the edge of the pool legs or head first and swim 25 to $50 \mathrm{~m}$ practicing any type of stroke.

\section{Data processing}

The following descriptive statistics were calculated: Mean value (Mean), standard deviation (SD), coefficient of variation $(\mathrm{Cv} \%)$ and Kolmogorov-Smirnov test (KS-p). To test the significance of differences in the arithmetic means on the initial and final assessment of the results of the study, a univariate variance analysis (ANOVA) was applied for each group of participants.

\section{RESULTS}

The mean values of all the applied tests show that the CG achieved better results at the final assessment in all variables, except for the bent arm hang. The achievements of the EG in the final assessment were better for all the variables.

The largest deviation from the mean value at the initial and final assessment, as indicated by the standard deviation, is in the case of the $20 \mathrm{~m}$ run (EFIZ), with the value of the standard deviation of the CG at an initial assessment of 50.55, and at the final one, 43.43. Similar findings were determined for the EG where the value of the standard deviation at the initial assessment is 63.24, and at the final 64.21. The lowest deviations from the mean values at the initial and final assessments of both groups are in the case of variables of the sit and reach test (EFPS). 
Table 1 Descriptive indicators and differences at the univariate level among the participants at the initial assessment

\begin{tabular}{lrrrrrrrrrr}
\hline & \multicolumn{3}{c}{ Control group } & \multicolumn{4}{c}{ Experimental group } & \multicolumn{3}{c}{ ANOVA } \\
\cline { 2 - 11 } Variables & Mean & \multicolumn{1}{c}{ SD } & Cv\% & KS-p & Mean & \multicolumn{1}{c}{ SD } & Cv\% & KS-p & F & p \\
\hline EFPS (cm) & 17.74 & 6.75 & 38.06 & .886 & 19.16 & 4.63 & 24.15 & .837 & 1.505 & .223 \\
EFSD (cm) & 143.21 & 30.81 & 21.51 & .899 & 156.36 & 25.81 & 16.51 & .986 & 5.353 & $\mathbf{. 0 2 3}$ \\
EFLS (reps) & 18.36 & 5.64 & 30.75 & .998 & 21.20 & 6.57 & 31.01 & .452 & 5.370 & $\mathbf{. 0 2 3}$ \\
EFZG (s) & 33.00 & 27.95 & 84.68 & .094 & 22.05 & 17.50 & 79.39 & .369 & 5.513 & $\mathbf{. 0 2 1}$ \\
EFIZ (s) & 168.90 & 50.55 & 29.93 & .728 & 191.84 & 63.24 & 32.97 & .984 & 4.014 & $\mathbf{. 0 4 8}$ \\
\hline
\end{tabular}

Legend: Mean - arithmetic mean value; SD - standard deviation; Cv\% - coefficient of variation; KS-p - Kolmogorov-Smirnov test; F - value of F test; $\mathrm{p}$ - level of statistical significance

In addition to this, the numerical values of the coefficients of variation indicate the homogeneity and heterogeneity of the set. The most homogeneous parameter at the initial and final assessments of both groups is the long-range jump (EFSD), while the smallest homogeneity was determined for the elevation in the joint at the initial and final assessments of both groups. The normal distribution of values was determined in all five experimental and $\mathrm{CG}$ variables of the experimental and $\mathrm{CG}$ at the initial and final assessment. The values of the Kolmogorov-Smirnov test indicate this.

In order to determine whether the observed differences were statistically significant, a univariate variance analysis (ANOVA) was applied.

At the initial assessment, a statistically significant difference was not determined only for the sit and reach test $(r=.223)$. A statistically significant difference in favor of the $\mathrm{CG}$ was determined for the variable of the bent arm hang $(r=.021)$. The statistically significant differences in the standing long jump ( $\mathrm{r}=.023)$, sit-ups for $30 \mathrm{~s}(\mathrm{r}=.023)$ and the $20 \mathrm{~m}$ run with a progressive increase in speed $(\mathrm{r}=.048)$ are all in favor of the experimental group, as indicators of its speed and agility (Tables 1 and 2).

Table 2 Descriptive indicators and differences at the univariate level among the participants at the final assessment

\begin{tabular}{lrrrrrrrrrc}
\hline & \multicolumn{3}{c}{ Control group } & \multicolumn{3}{c}{ Experimental group } & \multicolumn{3}{c}{ ANOVA } \\
\cline { 2 - 10 } Variables & Mean & \multicolumn{1}{c}{ SD } & Cv\% & KS-p & \multicolumn{1}{c}{ Mean } & SD & Cv\% & KS-p & F & p \\
\hline EFPS (cm) & 17.32 & 6.20 & 35.77 & .992 & 18.90 & 4.31 & 22.81 & .498 & 2.191 & .142 \\
EFSD (cm) & 146.36 & 28.57 & 19.52 & .995 & 156.84 & 24.30 & 15.49 & .968 & 3.904 & .050 \\
EFLS (reps.) & 19.70 & 5.18 & 26.27 & .912 & 22.88 & 6.42 & 28.06 & .341 & 7.436 & .008 \\
EFZG (s) & 32.00 & 22.59 & 70.61 & .179 & 23.66 & 15.80 & 66.78 & .403 & 4.575 & $\mathbf{. 0 3 5}$ \\
EFIZ (s) & 185.24 & 43.43 & 23.45 & .616 & 208.72 & 64.21 & 30.77 & .915 & 4.587 & $\mathbf{. 0 3 5}$ \\
\hline \multicolumn{1}{c}{ Legend: Mean - arithmetic mean value; SD - standard deviation; Cv\% - coefficient of variation; }
\end{tabular}

In the final assessment between the experimental and the CG, regardless of the better results of the EG, statistically significant differences were not observed for EFPS $(\mathrm{r}=.142)$ and the $10 \times 5 \mathrm{~m}(\mathrm{r}=.131)$. In the case of variables pertaining to the tests of speed and agility, a statistically significant difference in the final assessment in favor of the CG was determined for the bent arm hang $(\mathrm{r}=.035)$. The EG achieved statistically significantly better results in the standing long jump ( $\mathrm{r}=.050)$, sit-ups for $30 \mathrm{~s}(\mathrm{r}=.008)$, the $4 \times 10$ test of speed, and agility at the $20 \mathrm{~m}$ with progressive increase in speed $(\mathrm{r}=.035)$ (Table 2$)$. 
Table 3 Absolute and relative indicators of differences between the control and EG of participants related to the state of motor abilities at the initial and final assessment

\begin{tabular}{lrrrrrrrr}
\hline & \multicolumn{4}{c}{ Control group } & \multicolumn{4}{c}{ Experimental group } \\
\cline { 2 - 9 } Variables & \multicolumn{1}{c}{ Initial } & \multicolumn{1}{c}{ Final } & \multicolumn{1}{c}{ Abs } & \multicolumn{1}{c}{ Rel\% } & \multicolumn{1}{c}{ Initial } & \multicolumn{1}{c}{ Final } & \multicolumn{1}{c}{ Abs } & Rel\% \\
\hline EFPS (cm) & 17.74 & 17.32 & -0.42 & -2.36 & 19.16 & 18.90 & -0.26 & -1.36 \\
EFSD (cm) & 143.21 & 146.36 & 3.15 & 2.20 & 156.36 & 156.84 & 0.48 & 0.31 \\
EFLS (reps.) & 18.36 & 19.70 & 1.34 & 7.30 & 21.20 & 22.88 & 1.68 & 7.92 \\
EFZG (s) & 33.00 & 32.00 & -1.00 & -3.03 & 22.05 & 23.66 & 1.66 & 7.30 \\
EFIZ (s) & 168.90 & 185.24 & 16.34 & 9.67 & 191.84 & 208.72 & 16.94 & 8.79 \\
\hline
\end{tabular}

Legend: Initial - initial assessment; Final - final assessment; Abs - absolute values; Rel\% - relative values

Table 3 shows the absolute and relative indicators of the difference between the control and EG in terms of the state of their motor skills at initial and final assessment. Absolute and relative values are positive for the standing long jump, sit-ups for $30 \mathrm{~s}$ and the $4 \times 10$ test of speed, and agility at $20 \mathrm{~m}$.

Regular PE classes led to positive effects in the CG for the variable of the standing long jump for absolute $3.15 \mathrm{~cm}$, i.e., $2.20 \%$, sit-ups for $30 \mathrm{~s}$ for absolute 1.34 repetitions, or $7.30 \%$, and $4 \times 10$ test of speed and agility at $20 \mathrm{~m}$ for absolute $16.34 \mathrm{~s}$, or $9.67 \%$. Negative absolute and relative values are present in the variables of the sit and reach test (absolute value $-0.42 \mathrm{~cm}$, relative value $-2.36 \%$ ) and the bent arm hang (absolute value $-1 \mathrm{~s}$, relative value $-3.03 \%$ ).

The obtained results of the EG show that the absolute and relative values are positive for all variables, except for the variability of the sit and reach test where the absolute values were reduced by 0.26 repetitions, or by $1.36 \%$.

\section{DISCUSSION}

Comparing the achieved results with the results of elementary school children from other European countries, it is evident that the participants are below average in terms of the majority of tests that characterize the motor skills covered by the "Eurofit" battery. Based on previous studies, it can be concluded that girls of this age are more flexible than boys (Slater \& Tiggemann, 2010; Pelemiš, Pelemiš, Mitrović, \& Džinović-Kojić). At a younger school age, boys are more physically active than girls. According to Armstrong, Welsman, \& Kirby (2000), Kerić, Rubin, Ujsasi, Fratrić, \& Radulović (2017), the level of physical activity of boys does not decrease in this period, as is the case with girls.

During the onset of puberty, more girls than boys become inactive (Sollerhed, Apitzsch, Råstam, \& Ejlertsson, 2008). In recent years, more and more research has focused on the monitoring of physical development and development of motor abilities in children in the context of official PE classes (Wrotniak, Epstein, Dorn, Jones, \& Kondilis, 2006; Venetsanou \& Kambas, 2010; Colella \& Morano, 2011; Lemos, Avigo, \& Barela, 2012). In the analysis of the development of motor abilities in children, the abilities are mainly associated with morphological characteristics, especially with the height and mass of the body. The focus of these studies is, in most cases, the influence of body height and mass (Benefice \& Malina, 1996; Beunen et al., 1997; Stamenković, Bratić, Berić, \& Pantelić, 2017) and the calendar age on the motor skills of children (Milde et al., 2006; Tomaszewski, Milde, Sienkiewicz Dianzenza, \& Nowicki, 2007). 
The results of previous studies show that the main factors for evaluating the efficacy of swimmers are unsuitable for students who are still learning to swim and that they differ considerably from one another in terms of motor skills (Formosa, Mason, \& Burkett, 2011; Madureira, Bastos, Corrêa, Rogel, \& Freudenheim, 2012). Similar results were obtained by individuals studying the effects of additional hours of physical activity on the improvement of motor skills of students (Boyle-Holmes et al., 2010; Matvienko \& Ahrabi Fard, 2010; Ericsson, 2011). The abovementioned studies confirm the positive effects of additional physical activities on the transformation of motor skills of students, in comparison with the regular PE classes. Research in this area is primarily focused on swimming performance in relation to competitive distance (Tanaka, Costill, Thomas, Fink, \& Widrick, 1993; Sutarto et al., 2010; Neiva, Marques, Barbosa, Izquierdo, \& Marinho, 2014). The basic feature of the research is the modeling of top-quality swimmers (Smith, Norris, \& Hogg, 2002; Okičić, Madić, Dopsaj, \& Đorđević, 2007). As a result, it can be concluded that there is little research in the field of swimming training and that it can be one of the directions in swimming research and additional contents of teaching PE.

The obtained results in this research provide the arguments that students, in addition to their regular teaching PE classes, need to be introduced to additional PE classes, which would primarily meet the needs of students for physical activity and be a preventive measure for various types of diseases that occur due to obesity and insufficient activity. The swimming training program that has been realized will have long-term positive effects, not only because of the learned swimming techniques, but also because of the socialization of students who, through pleasant socializing during training, create a positive image of themselves and develop into complete and healthy personalities.

Increasing the number of PE classes in schools is an inevitable process, as it can be used to promote harmonious bio-psycho-social development in conditions of increasing hypokinesis. Due to positive action on the transformation of motor skills, swimming training should be the backbone of the PE system of preschool and school education.

In order to explain the importance of swimming to the students, it is also necessary to organize theoretical lectures where, with the help of multimedia presentations, students will be able to get to know swimming, jumping, and stroke techniques. By adopting this way of working, students would not only be provided with basic knowledge and skills in swimming, but also with the possibility for creative personal experiences both during theoretical classes and in practice for self-improvement and self-control. This kind of work would provide teachers and PE teachers with a more efficient organization of swimming training in the course of PE classes.

\section{CONCLUSION}

Theoretical research in the field of work with established programs and methods indicates positive results in swimming training, while practice shows that this mode of work has become stereotyped and governed by methodological uniformity. There is a need for the realization of swimming training, which will be modernized by new methods, and which will open new possibilities for thinking and introducing new approaches to previous stereotypes, with the necessary education of the teaching staff. 
Acknowledgement: The work was created within the project "Effects of applied physical activity on the locomotor, metabolic, psycho-social and educational status of the population of the Republic of Serbia" under the number III47015, supported by the Ministry of Education, Science and Technological Development of the Republic of Serbia.

\section{REFERENCES}

Armstrong, N., Welsman, J.R., \& Kirby, B.J. (2000). Longitudinal changes in 11-13-year-olds' physical activity. Acta Paediatrica, 89(7), 775-780.

Barbosa, T.M., Marinho, D.A., Costa, M.J., \& Silva, A.J. (2011). Biomechanics of competitive swimming strokes. In V. Klika (Ed.) Biomechanics in Applications, (pp. 367-388). Rijeka: In Tech.

Benefice, E., \& Malina, R. (1996). Body size, body composition and motor performances of mild-to-moderately undernourished Senegalese children. Annals of Human Biology, 23(4), 307-321.

Benjanuvatra, N., Edmunds, K., \& Blanksby, B. (2007). Jumping ability and swimming grab-start performance in elite and recreational swimmers. International Journal of Aquatic Research \& Education, 1(3), 231-241.

Beunen, G.P., Malina, R.M., Lefevre, J., Claessens, A.L., Renson, R., Kanden Eynde, B., et al. (1997). Skeletal maturation, somatic growth and physical fitness in girls 6-16 years of age. International Journal of Sports Medicine, 18(6), 413-419.

Boyle Holmes, T., Grost, L., Russell, L., Laris, B.A., Robin, L., Haller, E., et al. (2010). Promoting elementary physical education: Results of a school-based evaluation study. Health Education and Behavior, 37(3), 377-389.

Colella, D., \& Morano, M. (2011). Gross motor development and physical activity in kindergarten age children. International Journal of Pediatric Obesiti, 6(2), 33-36.

Davies, D., Jindal-Snape, D., Collier, C., Digby, R., Hay, P., \& Howe, A. (2013). Creative learning environments in education-A systematic literature review. Thinking Skills and Creativity, 8(1), 80-91.

Ericsson, I. (2011). Effects of increased physical activity on motor skills and marks in physical education: an intervention study in school years 1 through 9 in Sweden. Physical Education \& Sport Pedagogy, 16(3), 313-329.

Farrell, A. (2007). Cardiorespiratory performance during prolonged swimming tests with salmonids: a perspective on temperature effects and potential analytical pitfalls. Philosophical Transactions of the Royal Society B: Biological Sciences, 362(1487), 2017-2030.

Formosa, D.P., Mason, B., \& Burkett, B. (2011). The force-time profile of elite front crawl swimmers. Journal of Sports Sciences, 29(8), 811-819.

Girold, S., Maurin, D., Dugué, B., Chatard, J.C., \& Millet, G. (2007). Effects of dry-land vs. resisted- and assisted-sprint exercises on swimming sprint performances. Journal of Strength and Conditioning Research, 21(2), 599-605.

Gulías-González, R., Sánchez-López, M., Olivas-Bravo, Á., Solera-Martínez, M., \& Martínez-Vizcaíno, V. (2014). Physical fitness in Spanish schoolchildren aged 6-12 years: Reference values of the battery EUROFIT and associated cardiovascular risk. Journal of School Health, 84(10), 625-635.

Healey, M. (2005). Linking research and teaching to benefit student learning. Journal of Geography in Higher Education, 29(2), 183-201.

Jorgić, B., Puletić, M., Stanković, R., Okičić, T., Bubanj, S., \& Bubanj, R. (2010). The kinematic analysis of the grab and track start in swimming. Facta Universitatis Series Physical Education and Sport, 8(1), 31-36.

Kalaja, S., Jaakkola, T., Liukkonen, J., \& Watt, A. (2010). Fundamental movement skills and motivational factors influencing engagement in physical activity. Perceptual and Motor Skills, 111(1), 115-128.

Kerić, M., Rubin, P., Ujsasi, D., Fratrić, F., \& Radulović, N. (2017). Significance of the differences in motor abilities and morphological characteristics between boys and girls aged 9 to 11 for physical education optimization. Facta Universitatis Series Physical Education and Sport, 15(1), 115-123.

Kloos, C.D., Alario-Hoyos, C., Muñoz-Merino, P.J., Ibáñez, M.B., Estévez-Ayres, I., \& Crespo-García, R.M. (2019). What can you do with educational technology that is getting more human?. In A.K. Ashmawy, \& S. Schreiter (Eds.), 2019 IEEE Global Engineering Education Conference-EDUCON, 8-11 April 2019, (pp. 1480-1487). Dubai, United Arab Emirates.

Lemos, A.G., Avigo, E.L., \& Barela, J.A. (2012). Physical education in kindergarten promotes fundamental motor skill development. Advances in Physical Education, 2(1), 17-21. 
Macejková, Y., Masaryková, D., \& Labudová, J. (2008). Proportionality of load during swimming lessons of adults. Fitness \& Performance Journal (Online Edition), 7(3), 180-184.

Madureira, F., Bastos, F. H., Corrêa, U. C., Rogel, T., \& Freudenheim, A.M. (2012). Assessment of beginners' front-crawl stroke efficiency. Perceptual and Motor Skills, 115(1), 300-308.

Matvienko, O., \& Ahrabi Fard, I. (2010). The effects of a 4-week after-school program on motor skills and fitness of kindergarten and first-grade students. American Journal of Health Promotion, 24(5), 299-303.

Milde, K., Tomaszewski, P., Sienkiewicz-Dianzenza, E., Nowicki, D., Wisniewski, A., \& Stupnicki, R. (2006). Physical fitness of short-statured boys as related to percentile norms for calendar or growth age. Endokrynologia, Diabetologia $i$ Choroby Przemiany Materii Wieku Rozwojowego: Organ Polskiego Towarzystwa Endokrynologow Dzieciecych, 12(2), 127-130.

Neiva, H.P., Marques, M.C., Barbosa, T.M., Izquierdo, M, \& Marinho, D.A. (2014). Warm-up and performance in competitive swimming. Spotrs Medicine, 44(3), 319-313.

Okičić, T., Madić, D., Dopsaj, M., \& Đorđević, M. (2007). The math modeling of the stages of result development in high profile elite swimmers for the $50 \mathrm{~m}, 100 \mathrm{~m}, 200 \mathrm{~m}, 400 \mathrm{~m}$ and $1500 \mathrm{~m}$ freestyle. Facta Universitatis Series Physical Education and Sport, 5(2), 121-137.

Onurkan Aliusta, G., \& Özer, B. (2017). Student-centred learning (SCL): Roles changed?. Teachers and Teaching, 23(4), 422-435.

Pelemiš, V.M., Pelemiš, M.M., Mitrović, N.Z., \& Džinović-Kojić, D. (2014). Quantitative analysis of differences in morphological and motor status of pupils and their connection with agility. Facta Universitatis Series Physical Education and Sport, 12(2), 113-122.

Pešić, M., Okičić, T., Madić, D., Dopsaj, M., Đurović, M., \& Đorđević, S. (2016). The effects of additional strength training on specific motor abilities in young swimmers. Facta Universitatis Series Physical Education and Sport, 13(2), 291-301.

Pyne, D.B., \& Sharp, R.L. (2014). Physical and energy requirements of competitive swimming events. In International Journal of Sport Nutrition and Exercise Metabolism 24(4), 351-359.

Radovanović, D., Aleksandrović, M., Stojiljković, N., Ignjatović, A., Popović, T., \& Marinković, M. (2009). Uticaj treninga $\mathrm{u}$ preadolescentnom uzrastu na kardiorespiratornu izdržljivost (Influence of physical training on cardiorespiratory endurance in preadolescent age). Acta Medica Medianae, 48(1), 37-40. In Serbian

Sawyer, R.K. (2004). Creative teaching: Collaborative discussion as disciplined improvisation. Educational Researcher, 33(2), 12-20.

Slater, A., \& Tiggemann, M. (2010). Body image and disordered eating in adolescent girls and boys: A test of objectification theory. Sex Roles, 63(1), 42-49.

Smith, D.J., Norris, S.R., \& Hogg, J.M. (2002). Performance evaluation of swimmers: scientific tools. Sports Medicine, 32(9), 539-554.

Sollerhed, A.C., Apitzsch, E., Råstam, L., \& Ejlertsson, G. (2008). Factors associated with young children's self-perceived physical competence and self-reported physical activity. Health Education Research, 23(1), $125-136$

Stanković, S., Milanović, S., \& Marković, Ž. (2015). Use of basic synchronized swimming techniques in non swimmers trainings. Activities in Phisical Education \& Sport, 5(1), 82-85.

Stamenković, S., Bratić, M., Berić, D., \& Pantelić, S. (2017). The level of morpho-motor skills of seven-year-old boys of various nutritional status. Facta Universitatis Series Physical Education and Sport, 15(1), 125-137.

Sutarto, A.P., Wahab, M.N.A., \& Zin, N.M. (2010). Heart Rate Variability (HRV) biofeedback: A new training approach for operator's performance enhancement. Journal of Industrial Engineering and Management. 3(1), 176-198.

Swamidass, P.M., \& Vulasa, V. (2009). Why university inventions rarely produce income? Bottlenecks in university technology transfer. Journal of Technology Transfer, 34(4), 343-363.

Tanaka, H., Costill, D.L., Thomas, R., Fink, W.J., \& Widrick, J.J. (1993). Dry-land resistance training for competitive swimming. Medicine and Science in Sports and Exercise, 25(8), 952-959.

Tomaszewski, P., Milde, K., Sienkiewicz-Dianzenza, E., \& Nowicki, D. (2007). Physical fitness of short-statured children at the early-school age. Pediatric Endocrinology, Diabetes and Metabolism, 13(3), 125-128.

Tošić, S. (2011). The influence of flexibility on swimming results. Facta Universitatis Series Physical Education and Sport, 9(2), 193-202.

Tsigilis, N., Douda, H., \& Tokmakidis, S.P. (2002). Test-retest reliability of the Eurofit test battery administered to university students. Perceptual and Motor Skills, 95(3), 1295-1300.

Venetsanou, F., \& Kambas, A. (2010). Environmental factors affecting preschoolers' motor development. Early Childhood Education Journal, 37(4), 319-327.

Wrotniak, B.H., Epstein, L.H., Dorn, J.M., Jones, K.E., \& Kondilis, V.A. (2006). The relationship between motor proficiency and physical activity in children. Pediatrics, 118(6), 1758-1765. 


\section{UTICAJI NA REGULARNE NASTAVE FIZIČKOG VASPITANJA I NASTAVE SA DODATNIM VEŽBAMA NA MOTORIČKE SPOSOBNOSTI STUDENATA}

Cilj istraživanja bio je da se uporede nastava fizičkog vaspitanja sa dodatnim treninzima plivanja i redovna nastava fizičkog vaspitanja i ispitaju uticaji na motoričke sposobnosti učenika mlađeg školskog uzrasta. Uzorak od 100 ispitanika podeljen je u dva subuzorka u odnosu na broj nedeljnih vežbi: subuzorak od 50 učenika (kontrolna grupa-KG) sa redovnom nastavom fizičkog vaspitanja i subuzorak od 50 učenika (eksperimentalna grupa-EG) koji su pored redovnih časova imali dodatno i dva treninga plivanja nedeljno. Program obuke kurseva plivanja sprovodio se tokom tri meseca prvog polugođa školske godine 2015/2016. U proceni motoričkih sposobnosti korišćeno je pet standardizovanih testova Eurofit baterije. Rezultati ukazuju na to da su dva treninga plivanja nedeljno uzrokovale statistički značajne razlike između EG i CG u trčanju na duge staze, trbušnjacima u trajanju od $30 \mathrm{~s}$ i trčanju na $20 \mathrm{~m}$ sa progresivnim prirastom u brzini. Rezultati ukazuju da plivanje pored već poznatog fiziološkog uticaja pozitivno utiče na transformaciju motoričkih sposobnosti kod učenika mlađeg školskog uzrasta.

Ključne reči: fizičko vaspitanje, plivanje, motoričke veštine, učenici mlađeg školskog uzrasta 